\title{
RIZIČNI FAKTORI ZA RAZVOJ SKLONOSTI SAMOUBISTVU
}

\section{Sažetak}

Postoji značajan interes istraživača za ispitivanje prisustva rizičnih faktora za razvoj sklonosti samoubistvu na razini ideja o samoubistvu, pokušaja samoubistva $i$ izvršenog samoubistva. Cilj ovog preglednog rada je ponuditi jasan i konzican pregled naučnih spoznaja o socioedemografskim, psihološkim, psibijatrijskim i tjelesnim rizičnim faktorima za razvoj sklonosti samoubistvu, te odgovoriti na pitanje o mehanizmima koji leže podlozi njihovih odnosa. Korištena je recentna literatura iz područja sklonosti samoubistvu s naglaskom na radove objavljene u posljednjih petnaest godina.

$\mathrm{Na}$ temelju kritičkog pregleda dosadašnjih spoznaja, prema dostupnim podacima, zaključeno je da postoje snažni dokazi o prisustvu odredenih sociodemografskih, psiholoških, psihijatrijskih i tjelesnih faktora koji pojedinca mogu činiti vulnerabilnim za razvoj sklonosti samoubistvu na bilo kojoj razini. Njihovim kumuliranjem javlja se i porast rizika od samoubistva. Kliničke implikacije ovog preglednog rada uključuju mogućnost praktične primjene naučno utemeljenih rezultata istraživanja, te njihovo korištenje u kliničkoj praksi s ciljem unaprijeđivanja psihološke procjene sklonosti samoubistvu. Pravovremeno prepoznavanje, otkrivanje i tretiranje faktora rizika ključna je komponenta za razvijanje strategije prevencije sklonosti samoubistvu, kao i odredivanje najprikladnije vrste intervencije.

Ključne riječi: sklonost samoubistvu, ideje o samoubistvu, pokušaj samoubistva, izvršeno samoubistvo, rizični faktori

\section{UVOD}

Procjenjuje se da svake godine najmanje milion ljudi u svijetu izvrši samoubistvo, što znači da se gotovo svakih četrdesetak sekundi, svjesnom i sopstvenom namjerom, ugasi jedan život (WHO, 2005). Samoubistva predstavljaju svi slučajevi smrti koji su direktna i indirektna posljedica pozitivnog ili negativnog čina same žrtve koja zna kakva će posljedica tog čina biti (WHO, 2005). Bitno širi i sveoubuhvatniji pojam je sklonost samoubistvu koji nam sugerira 
raznolikost autodestruktivnog ponašanja koja se kreću od ideja o samoubistvu, pokušaja samoubistva i na koncu izvršenog samoubistva (Aziraj-Smajić, 2014a).

O navedenom fenomenu i općenito obradi ove teme u literaturi postoje brojne kontradiktornosti. Postavljaju se pitanja i problemi kliničke procjene sklonosti samoubistvu, jer su podaci u ovim istraživanjima velikim dijelom prikupljeni isključivo na osnovu psihijatrijskog intervjua i skala samoprocjene. S druge pak strane, autori upozoravaju da se u procjeni rizika za razvoj sklonosti samoubistvu nikako ne smijemo osloniti isključivo na podatke dobivene tokom intervjua, jer pacijenti koji zaista žele počiniti samoubistvo najčešće zdravstveno osoblje posmatraju kao „neprijatelje”, (prijetnju počinjenju krajnjeg čina samoubistva), te u skladu s tim i poriču svoje ideje, namjere $\mathrm{i}$ planove u vezi samoubistva (Resnik, 2002). U literaturi se naglašava i značaj psihološke procjene rizika za razvoj sklonosti samoubistvu koja osim direktnih (neposrednih) tehnika, kao što su intervju, upitnici i skale samoprocjene, uključuju i indirektne (posredne) tehnike. Prednost indirektnih tehnika se ogleda upravo u činjenici da se rizik ta razvoj sklonost samoubistvu procjenjuje preko mjera psiholoških faktora (kognitivnih obilježja i obilježja ličnosti) čija je povezanost s različitim izražavanjima u ovom području dobro empirijski potkrijepljena (Akrap, 2011).

Kao osnovni metodološki problem $u$ istraživanjima izvršenih samoubistava javlja se činjenica da je osoba koja je izvršila samoubistvo istraživačima nedostupna, te otuda potječu i najznačajnija metodološka ograničenja vezana za ova istraživanja. Postavlja se pitanje predviđaju li podaci dobiveni na uzorku pojedinaca koji su pokušali samoubistvo obilježja onih koji se zaista ubiju, a s druge strane, jesu li rezultati istraživanja dobiveni metodom psihološke autopsije (kada predmet istraživanja više ne postoji) zapravo relevantni i validni za zaključivanje o istinskoj prirodi i etiologiji njihove sklonosti samoubistvu (Portzky, Audenaert i Van Heeringen, 2005).

U literaturi uvjerljivo dominiraju istraživanja pokušanih samoubistava, jer mnogi autori smatraju da je najveći rizični faktor za izvršenje samoubistva upravo njegov pokušaj (Borges i sur., 2006; 2008; Giegling i sur., 2009; Sareen, Cox, Afifi, de Graaf i Asmundson, 2005). 
Međutim, postoje i suprotna stajališta koja ukazuju na mogućnost razlikovanja osoba koje izražavaju ideje o samoubistvu od onih koje su ga pokušale, te onih koje su ga izvršile (Van Heeringen, 2001). Teorijski posmatrano, metodološke poteškoće prvenstveno proizilaze iz problema definiranja samoubistva i pokušaja samoubistva.

Nadalje, još jedna od teškoća u okviru ovog područja proizilazi iz problema dijagnostičke procjene rizika za razvoj sklonosti samoubojstvu. Naime, prema Međunarodnoj klasifikaciji bolesti i srodnih zdravstvenih problema (MKB-10) ili Dijagnostičkostatističkom priručniku za mentalne poremećaje (DSM IV), nema zasebnog klasificiranja pokušaja samoubistva niti izvršenog samoubistva. Obje klasifikacije su u odnosu na sklonost samoubistvu vrlo neprecizne i nedorečene, te zapravo ne sadrže posebnu dijagnostičku šifru koja bi upućivala na prisustvo navedenog fenomena, već bi ona trebala biti prepoznatljiva iz šifre osnovne dijagnoze. Posebnu teškoću u klasifikaciji sklonosti samoubistvu uvodi grupa koja se odnosi na nejasnoću između namjerno i nehotice izvršenih radnji koje mogu dovesti do smrtnog ishoda kao što je npr. predoziranje drogom (Aziraj-Smajić, 2014a). Iz navedenog proizilazi naučnoistraživački izazov bavljenja ovako kompleksnom pojavom kao što su rizični faktori za razvoj sklonosti samoubistvu, te općenito sklonost samoubistvu na svim razinama.

Očekivani doprinos ovog preglednog rada moguće je sagledati s njegovog teorijskog i praktičnog značaja. Teorijski doprinos očituje se prvenstveno u prezentiranju naučno utemeljenih rezultata recentnih istraživanja i dobivanju spoznaje i produbljenih znanja o sklonosti samoubistvu u općoj i psihijatrijskoj populaciji. Opravdano je očekivati da ovakav pregled rezultata dosadašnjih istraživanja može potaknuti interes bosansko-hercegovačkih istraživača da se bave ovim naučnim područjem, kao da i navedene informacije mogu biti od koristi profesionalcima iz oblasti mentalnog zdravlja u njihovoj kliničkoj praksi.

\section{CILJ PREGLEDNOG RADA}

Cilj rada je dati jasan i cjelovit prikaz naučnih spoznaja o socioedemografskim, psihološkim, psihijatrijskim i tjelesnim faktorima 
koji se povezuju s rizikom za razvoj sklonosti samoubistvu, te odgovoriti na pitanje o mehanizmima koji leže podlozi njihovih odnosa.

\section{METODA RADA}

3.1. Kriteriji za uključivanje relevantnih istraživanja u pregledni rad

Istraživanja koja su uključena u ovaj pregledni rad su selekcionirana prema slijedećim kriterijima:

1. da su objavljena u recenziranim časopisima u razdoblju od 2001. do 2016. godine $\mathrm{i}$ to na engleskom, bosanskom jeziku, hrvatskom i srpskom jeziku

2. da uključuju bilo koje ispitivanje/procjenu rizičnih faktora sklonosti samoubojstvu kod odraslih osoba iz opće ili psihijatrijske populacije

3. da uzorak u tim istraživanjima obuhvaća učesnike starosne dobi od 18 godina i starije.

Uz pomoć unaprijed definiranih kriterija obuhvatili su se radovi koji svojom brojnošću (vremensko razdoblje $>15$ godina), raznolikošću (sve vrste traumatskih iskustava) i homogenošću (odrasli učesnici) doprinose pouzdanosti zaključivanja o faktorima koji su povezani sa rizikom od razvoja sklonosti samoubistvu. Za temeljne spoznaje koje su potrebne za ovaj rad koristile su se i usko specijalizirane knjige iz područja PTSP-a i suicidalnosti.

\subsection{Strategija pretraživanja za identifikaciju relevantnih studija}

U svrhu određivanja svih relevantnih istraživanja koja su bile uključene u pregledni rad vršilo se pretraživanje potencijalnih članaka putem elektroničkih pretraživača PsycINFO (2001-2012), PubMed (20012012), PILOTS (2001-2012), SpringerLink (2001-2012), EBSCO Academic Research (2001-2012). Riječi za pretraživanje su bile rizični faktori, sklonost samoubistvu, ideje o samoubistvu, pokušaji samoubistva i izvršena samoubistva, a predstavljale su egzaktne fraze $u$ naslovu rada, njegovom sažetku ili u ključnim riječima.

\section{PREGLED REZULTATA ISTRAŽIVANJA}

Određeni aspekti svakodnevnog života pojedinca mogu povećati vjerovatnost da će taj pojedinac imati ideje o samoubistvu, da će 
pokušati ili izvršiti samoubistvo. Na temelju pregleda rezultata dosadašnjih istraživanja, brojni rizični faktori mogu doprinijeti ovoj pojavi. Radi bolje preglednosti klasificiraju se u nekoliko grupa i to: sociodemografske, psihološke, psihijatrijske i tjelesne rizične faktore.

\subsection{Sociodemografski rizični faktori}

Ključni rizični faktori sklonosti samoubistvu su sociodemografska obilježja kao što su dob starija od 60 godina (Lloyd i Yip, 2001) muški spol i niži socioekonomski status (Mäki i Martikainen, 2007). Snažan prediktivni faktor sklonosti samoubistvu je i bračni status i to kada se radi o samcima, udovcima, razvedenima i onim koji su odvojeni od partnera (Lloyd i Yip, 2001; Holmes i Holmes, 2005). Niža sklonost samoubistvu je pokazana kod osoba koje žive u bračnoj zajednici (Stack, 2000; Lloyd i Yip, 2001). Također, istraživanja upućuju na podatak da je udovištvo povezano sa višim suicidalnim rizikom bez obzira na spol, ali da se posebno značajnim rizičnim faktorom pokazalo u populaciji vrlo mladih i starijih osoba (Agerbo, Qin i Mortensenm, 2006). Osobe nižeg obrazovnog statusa i samci imaju viši rizik od izvršenog samoubistva u poređenju s osobama koje su u braku (Lorant, Kunst, Huisman, Bopp i Mackenbach, 2005). Utjecaj bračne zajednice, kao i raspada te veze se razlikuje s obzirom na spol i starosnu dob (Mastekaasa, 2006).

Muškaraci dominiraju u izvršenim samoubistvima, dok žene u pokušanim samoubistvima. Diferencijacija sklonosti samoubistvu $u$ odnosu na rodnu perspektivu još uvijek nije u potpunosti razjašnjena. Neki autori uzroke toj pojavi traže u različitom načinu ekspresije agresije između muškaraca i žena zbog tradicionalno različitog načina odgoja za rodnu ulogu. U posljednje vrijeme ovo se argumentira i podacima prema kojima muškarci češće primjenjuju metode samoubistva s većom mogućnošću letalnog ishoda (upotreba vatrenog oružja, vješanje), dok žene primjenjuju metode s manjom mogućnošću letalnog ishoda (medikamenti..) (Aziraj-Smajić, 2013).

Novija istraživanja sugeriraju značaj faktora kao što su niža razina obrazovanja i mlađa životna dob (Suokas i sur., 2010). Rezultati istraživanja koje je obuhvatilo osobe s PTSP-om upućuje na podatak da su osobe sklone samoubistvu češće bile nisko obrazovane (završena OŠ i niže), dok je među visokoobrazovanim osobama bilo podjednako 
onih koje su pokazivale sklonost samoubistvu i one koje nisu imale tih sklonosti (Aziraj-Smajić, 2014a). Ipak, istraživanja upućuju na podatak da osobe s višim obrazovnim nivoom mogu biti sklonije izvršavanju samoubistva kada se suočavaju s neuspjesima, javnom sramotom i sličnim problemskim situacijama (Pompili, Vichy i Girardi, 2012).

Kao bitan faktor sklonosti samoubistvu spominje se i nezaposlenost (Ahs i Westerling, 2006; Aziraj-Smajić, 2014a; Blakely, Collings i Atkinson, 2003; King i sur., 2001; Lundin, Lundberg, Allebeck i Hemmingson, 2012; Pitman, Krysinska, Osborn i King, 2012; Ruuhela, Hiltunen, Vanäläinen, Pirinen i Partonen, 2009; Yim, Yip, Li, Dunn, Yeung i Miao, 2004). U vezi s tim, neizostavno je spomenuti da je $\mathrm{u}$ $\mathrm{BiH}$ stopa nezaposlenosti izrazito visoka. Da bismo jasnije shvatili kretanje stope nezaposlenosti u proteklih nekoliko godina, ukratko ćemo prikazati osnovne pokazatelje ove nemile pojave u našoj zemlji. Naime, prema podacima Federalnog zavoda za zapošljavanje početkom 2012. godine na evidencijama Službi za zapošljavanje su bile registrirane 374.294 osobe. Udio ženske populacije u broju nezaposlenih iznosi 191.915, odnosno 51,27\%. Što se tiče obrazovnog statusa, odnosno kvalifikacione strukture nezaposlenih, među njima najviše je KV (128.620 ili 34,36\%) i NKV radnika (119.361 ili $31,89 \%$ ), potom slijede osobe sa SSS (90.735 ili 24,24\%) i VSS (18.961 ili 5,07\%), PKV radnici (8.592 ili 2,30\%), osobe sa VŠS (5.016 ili 1,34\%), VKV radnici (2.242 ili 0,60\%) i osobe s NSS (767 ili 0,20\%). Najveći broj nezaposlenih registriran je u Tuzlanskom (96.057 ili 25,66\%), potom u Kantonu Sarajevo (70.700 ili 18,89\%) i Zenickodobojskom kantonu (67.422 ili 18,01\%). U Bosansko-podrinjskom kantonu su registrirane 3.794 nezaposlene osobe ili 1,01\% od ukupnog broja (Bilten Federalnog zavoda za zapošljavanje Sarajevo, 2012).

Na Slici 1., 2. i 3. prikazani su podaci o ukupnom broju nezaposlenih, zatim podaci o ukupnom broju nezaposlenih demobilisanih boraca, te podaci o ukupnom broju ratnih vojnih invalida na području Federacije Bosne i Hercegovine u periodu 2011. i 2012. godine.

Činjenica je da su nezaposleni demobilisani borci kao i nezaposleni ratni vojni invalidi posebno ugroženi dio bosansko - hercegovačkog društva. Veliki dio njih još uvijek pokušava zaboraviti na ratne traume i uključiti se u svakodnevni život. Dio njih to uspijeva uz psihijatrijsku pomoć, a dio njih nažalost izlaz na kraju potraži u dizanju ruke na sebe. 
Očigledno je da sve njih posebno teško pogađa „društvena nepravda”, a posebno u pogledu njihovog neriješenog radnog statusa u državi za čiju slobodu i dobrobit su se borili. Svemu gore navedenom u prilog idu i podaci da stope samoubistava rastu u doba ekonomske nestabilnosti (Barth i sur., 2011).

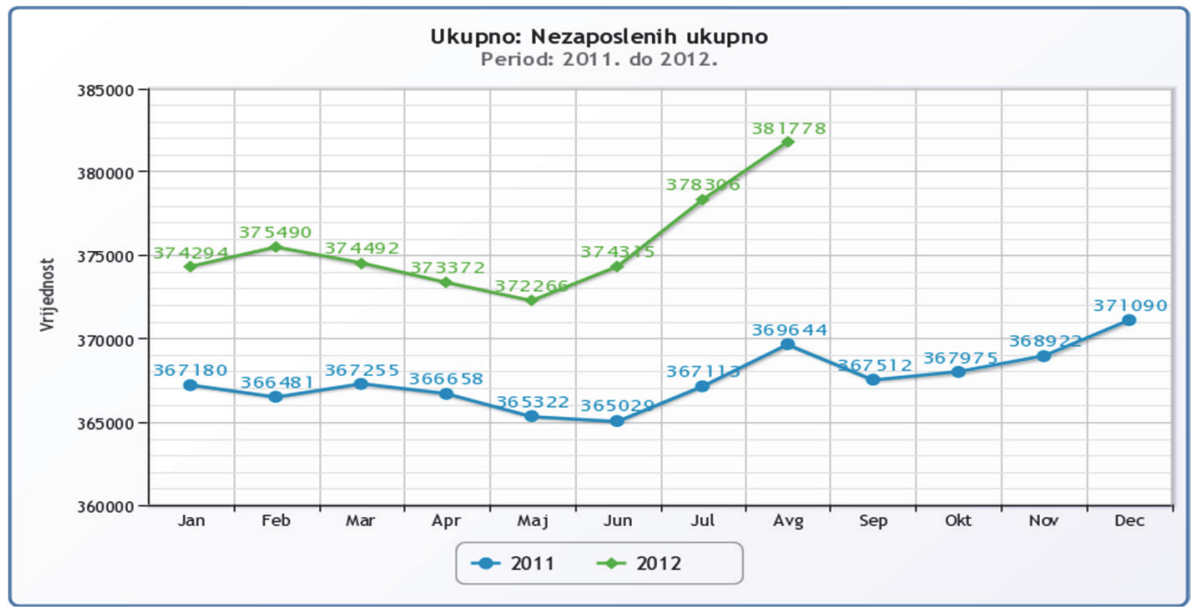

Slika 2. Prikaz ukupnog broja nezaposlenih na području Federacije Bosne i Hercegovine u periodu 2011. i 2012. godine prema registru Federalnog zavoda za zapošljavanje Sarajevo (Federalni zavod za zapošljavanje, 2012).

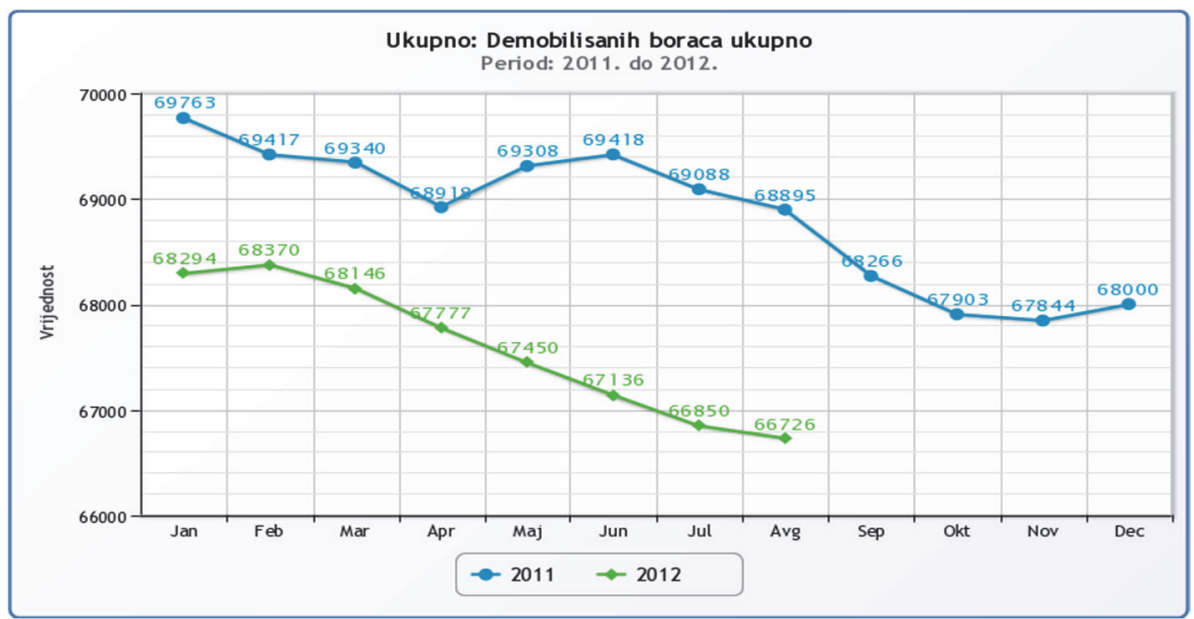

Slika 3. Prikaz ukupnog broja nezaposlenih demobilisanih boraca na području Federacije Bosne i Hercegovine u periodu 2011. i 2012. godine, prema registru Federalnog zavoda za zapošljavanje Sarajevo (Federalni zavod za zapošljavanje, 2012). 


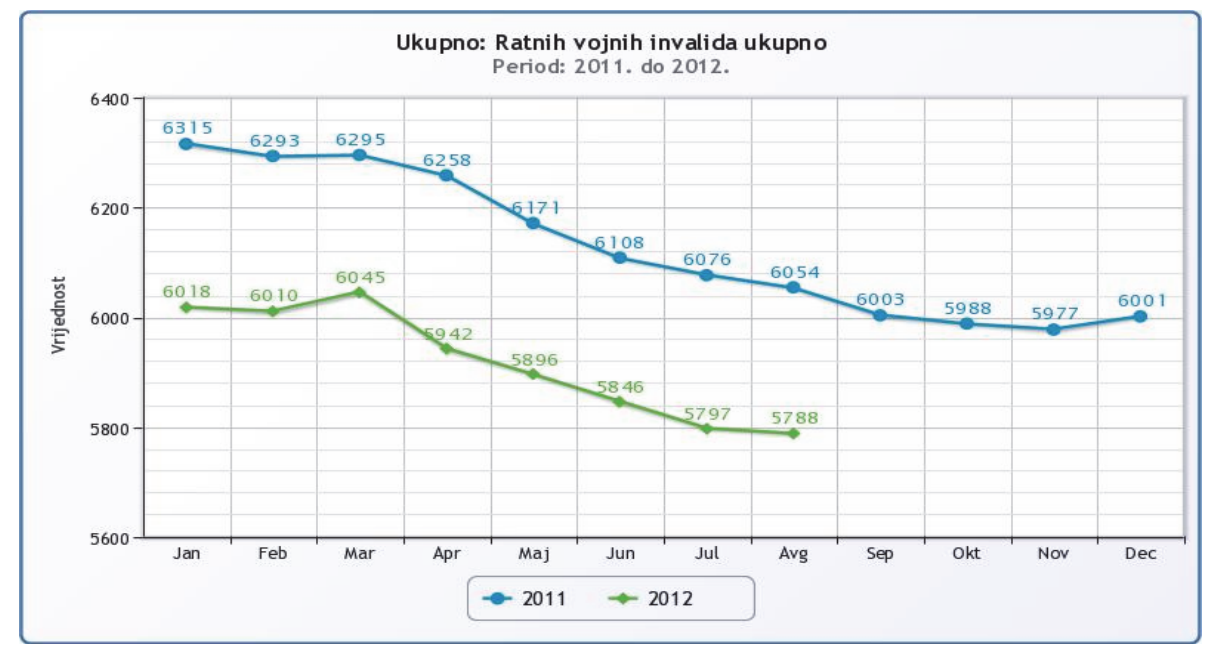

Slika 4. Prikaz ukupnog broja nezaposlenih ratnih vojnih invalida na području Federacije Bosne i Hercegovine u periodu 2011. i 2012. godine, prema registru Federalnog zavoda za zapošljavanje Sarajevo (Federalni zavod za zapošljavanje, 2012).

Prema najnovijim podacima Federalnog zavoda za zapošljavanje $\mathrm{u}$ našoj zemlji je čak 450. 833 nezaposlene osobe, od čega je 55. 734 demobilisana borca (Federalni zavod za zapošljavanje, 2016). Naime, kada sklonost samoubistvu dovodimo u vezu sa nezaposlenošću značajno je spomenuti rezultate istraživanja koji upućuju na podatak da nezaposlenost utječe na povećanje depresivnosti kod muškaraca $s$ obzirom da to za njih može značiti ne samo pometnju i/ili krah njihove profesionalne karijere, već i svojevrstan atak na njihov indentitet hranitelja porodice. Ono što se u ovim slučajevima vezuje za porast sklonosti samoubistvu je reakcija muškaraca na depresiju i njihov otpor za traženje pomoći u tim situacijama (Branney i White, 2008).

\subsection{Psihološki rizični faktori}

Među psihološkim rizičnim faktorima dominiraju osjećaj beznađa i manje vrijednosti, traumatski događaji u djetinjstvu, izostanak emocionalne podrške, te bračni problemi (Kim i sur., 2003; Power i sur., 2003). Naime, već su ranija istraživanja pokazala da osjećaj beznađa predstavlja važan dio kognitivnih distorzija depresivnih osoba i osoba sklonih samoubistvu (Beck i sur., 1989; Beck i Weishaar, 1990), te da je upravo taj faktor ključni prediktor sklonosti samoubistvu (Nimeus, Traskman-Bendz i Alsen, 1997). Noviji podaci ukazuju na 
značajan utjecaj osjećaja beznađa na sklonost samoubistvu kod osoba s bipolarnim poremećajem raspoloženja (Acosta i sur., 2012). Čak postoje podaci genetičkih studija koji govore u prilog potencijalnom fenotipskom učinku osjećaja beznađa koji posreduje između TPH2 gena (eng. tryptophan hydroxylase), depresije i sklonosti samoubistvu (Lazary i sur., 2012).

Nadalje, pokazane su značajne razlike među osobama koje su pokušale samoubistvo $\mathrm{i}$ to $\mathrm{s}$ obzirom na to da li je taj čin bio rezultat impulzivnosti ili je pak bio rezultat ranijeg dugotrajnijeg promišljanja. Naime, osobe koje su impulzivno pokušale samoubistvo pokazale su niže rezultate na skalama depresivnosti i beznađa od osoba koje su to učinile s predumišljajem (Spokas, Wenzel, Brown i Beck, 2012). Također, pored osjećaja beznađa, povišenoj sklonosti samoubistvu značajno doprinosi i nedostatak povezanosti sa drugima (Daniel i Goldston, 2012) koji se definira kao manjak socijalne podrške, slaba integriranost $\mathrm{u}$ socijalnu mrežu, te percepcija socijalne izolacije (Kaminski i sur., 2010).

$\mathrm{Na}$ temelju rezultata istraživanja koje bavilo ispitivanjem psihopatoloških obilježja manifestiranih na Minnesota multifazičnom inventaru ličnosti-202 (MMPI-202) osoba s PTSP-om s obzirom na prisustvo sklonosti samoubistvu, saznaje se o značajnim razlikama između onih koji su skloni i onih koji nisu skloni samoubistvu suicidalnih i nesuicidalnih osoba s PTSP-om. U vezi s tim, utvrđena je značajno veća razina psihopatoloških obilježja na skali histerije (Hy) i hipomanije (Ma) kod osoba s PTSP-om kod osoba koje nisu sklone samoubistvu. Nadalje, u ovom istraživanju skale psihopatske devijacije $(\mathrm{Pd})$, paranoje $(\mathrm{Pa})$ i psihastenije $(\mathrm{Pt})$ su bile više izražene kod osoba $\mathrm{s}$ PTSP-om koje su sklone samoubistvu (Aziraj-Smajić, 2014a).

Kao najznačajni prediktori ideja o samoubistvu i pokušaja samoubistva (na uzorku od 1117 muških zatvorenika) pokazale su se tri psihološke varijable, a to su trauma proživljena u djetinjstvu, emocionalna labilnost i ovisnost o supstancama. Pojedinci koji su skloni samoubistvu su pokazivali niže skorove na skali ekstraverzije, dok su više skorove pokazivali na skalama neuroticizma, psihoticizma, agresivnosti, hostilnosti i depresivnosti (Sarchiapone i sur., 2009). Također, sve se više obraća pažnja na samokriticizam (pretjerano kritičko vrednovanje 
vlastitog ponašanja) i ruminaciju kao značajne prediktore rizika od samoubistva (Morrison i O' Connor, 2008; O’Connor i Noyce, 2008).

$\mathrm{Na}$ temelju kritičkog pregleda dosadašnjih spoznaja saznajemo da kognitivna vulnerabilnost može predisponirati osobu za sklonost samoubistvu, te se i spominje kao jedan od značajnih rizičnih faktora $\mathrm{u}$ ovom području (O'Connor, Sheehy i O'Connor, 2000). Nizak IQ je povezan s većim suicidalnim rizikom u općoj populaciji (Gunnell i sur., 2005). Međutim, u populaciji osoba s ozbiljnim psihijatrijskim poremećajima veći suicidalni rizik je povezan s višim IQ-om (Hawton i sur., 2005). Ipak, postojeće studije provedene na ratnim veteranima govore u prilog sasvim suprotnih rezultata (Jokić-Begić, 2005). Istraživanje koja je obuhvatilo osobe $s$ dijagnosticiranim civilnim $\mathrm{i}$ ratnim PTSP-om, provedeno u $\mathrm{BiH}$, upućuje na podatak da se osobe koje su sklone samoubistvu i osobe koje nisu sklone samoubistvu značajno razlikuju u razini općeg intelektualnog funkcioniranja (AzirajSmajić, 2014a). Navedeno istraživanje je pokazalo da osobe koje nisu sklone samoubistvu, a imaju dijagnosticiran PTSP, postižu značajno više rezultate $u$ odnosu na osobe koje su hospitalizirane na odjel psihijatrije radi povišenog rizika od samoubistva i osobe koje su ranije pokušale samoubistvo. Viši IQ se kod osoba s PTSP-om pokazao kao značajan zaštitni faktor koji doprinosi efikasnijim kognitivnim proradama traumatskih iskustava, adekvatnijem reagiraju na promjene, kao i primjeni adekvatnijih strategija za svakodnevno suočavanje sa stresom. Sugerira se da osobe koje nisu sklone samoubistvu imaju bolju sposobnost da se zamisle na drugom mjestu i u drugom vremenu $-\mathrm{u}$ budućnosti, da optimističnije gledaju na budućnost, da uspijevaju napraviti svojevrstan odmak od potencijalnih preplavljujućih tegoba, te da budu otvoreniji ka novim iskustvima (Aziraj-Smajić, 2014a).

Također, studije ukazuju na povezanost određenog neuropsihološkog funkcioniranja i sklonosti samoubistvu po kojem se razlikuju agresivne osobe od osoba sklonih samoubistvu. Pokazano je da je viša stopa agresije prisutna kod pacijenata s općom deterioracijom intelektualnih funkcija, s poremećajima koncentracije i pažnje, te s deficitima izvršnih funkcija (Serper i sur., 2008; Harris i sur., 2010; Huber i sur., 2012). Veća stopa sklonosti samoubistvu je bila prisutna kod pacijenata $\mathrm{s}$ primarno nižim intelektualnim funkcioniranjem, oslabljenom pažnjom i oštećenim izvršnim funkcijama, a upravo ova obilježja dovode do 
višeg stepena impulzivnosti što povećava rizik od samoubistva (Garcia Espinosa i sur., 2010). Bolje izvršno funkcioniranje podrazumijeva da osoba ima bolju spoznaju i sposobnost da zamišlja planove potencijalnog samoubistva, što dovodi i do povišenog rizika od samoubistva (Nangle i sur., 2006). Relativno bolje izvršno funkcioniranje kod osoba sklonih samoubistvu može doprinijeti boljoj sposobnosti planiranja samoubistva i iniciranja cilju usmjerenih aktivnosti kao što je izvršavanje samoubistva. Osim toga, sposobnost brzog reagiranja kod osoba sklonih samoubistvu može značiti i impulzivnost (Vigil-Colet i Codorniu-Raga, 2004) što dalje može doprinijeti većem riziku od izvršenog samoubistva (Oquendo i sur., 2004). Također, kao značajan faktor u literaturi se spominje i sposobnost uvida u svoje tegobe (Maltzer, 1998).

Novije studije ukazuju na pozitivnu povezanost između konstrukta anksiozne osjetljivosti i sklonosti samoubistvu (Capron i sur., 2011; Capron, Cougle, Ribeiro, Joiner i Schmidt, 2011). Rezultati kroskulturalnog transverzalnog istraživanja provedenog u Rusiji upućuju da osobe s visokom razinom anksiozne osjetljivosti imaju povišen rizik za pojavu ideja o samoubistvu. Kao najsnažniji prediktivni faktor pojavljuje se međudjelovanje visoke razine anksiozne osjetljivosti (kognitivne brige) s niskom razinom fizičke brige s obzirom da se takve osobe nemaju strah od fizičke boli (Capron i sur., 2012). Pored direktne povezanosti sa sklonošću samoubistvu od posebnog je značaja podatak da se anksiozna osjetljivost povezuje s razvojem psihopatologije i to različitih anksioznih poremećaja uključujući PTSP (Marshall i sur., 2010), kao i poremećaja vezanih za zloupotrebu psihoaktivnih supstanci (Schmidt, Buckner i Keough, 2007). Marshall i suradnici (2010) ukazuju na prediktivnu ulogu anksiozne osjetljivosti u razvoju PTSP-a kod osoba koje su hospitalizirane nakon zadobivenih težih tjelesnih ozljeda, a usljed proživljenog civilnog traumatskog iskustva. Višestruko je potvrđivana i značajna povezanost između više razine anksiozne osjetljivosti i izraženijih simptoma PTSP-a kako kod djece tako i kod odraslih osoba (Simpson i sur., 2006; Berenz i sur., 2012). Također, postoje nalazi da anksiozna osjetljivost može i predisponirati osobe za razvoj posttraumatskih stresnih reakcija (Asmundson i Stapleton, 2008). Pregledom dostupne literature mehanizam odnosa između anksiozne osjetljivosti, PTSP-a i sklonosti samoubistvu do sada nije istraživan. 
Nadalje, u vezu sa sklonošću samoubistvu dovode se i smetnje iz kruga problema spavanja. Neovisno o prisustvu nekog psihičkog poremećaja, noćne more se javljaju kao značajan rizični faktor za pojavu rizika od samoubistva (Nadorf, Anestesis, Nadorf, Harris i Wiener, 2013). Kada se javljaju u sklopu klastera simptoma PTSP-a predstavljaju snažan prediktivni faktor za pojavu sklonosti samoubistvu i to dominantno kod muškaraca, dok takvu ulogu kod žena preuzimaju nesanice (AzirajSmajić, 2014b).

Kao značajni rizični faktori u literaturi se spominju i akutne psihosocijalne krize, te predispozicije kao što su osobine ličnosti pesimizam, impulzivnost i agresivnost (Alaräisänen i sur., 2007; Hawton i van Heeringen, 2009). Naime, interesantno je da neka istraživanja pokazuju da su osobe koje impulzivno pokušavaju samoubistvo (bez predumišljaja prije pokušaja) manje depresivne, manje beznadne i s očekivanjima da će njihovi pokušaji samoubistva biti manje smrtonosni. Međutim, kako je smrtnost njihovih pokušaja samoubistva slične razine ozbiljnosti kao i kod osoba koje su pokušale samoubistvo s predumišljajem, upravo ovaj podatak jedno je svojevrsno upozorenje kliničarima da rizične faktore sklonosti samoubistvu pažljivo prostudiraju na svakom pojedinom slučaju (Spokas i sur., 2012). Također, pokazano je da društveno poticani perfekcionizam ima medijacijsku ulogu u odnosu između inhibiranog ponašanja i ideja o samoubistvu (Rasmussen, Elliott i O' Connor, 2012).

Pokazano je da stresni životni događaji mogu biti precipitirajući faktori pokušaja samoubistva kod osoba koje prvi put pokušavaju samoubistvo i osoba koje imaju ponavljane pokušaje samoubistva (Pompili i sur., 2011). Ahn i suradnici (2012) sugeriraju da posebno stresni događaji imaju značajan utjecaj na početak procesa sklonosti samoubistvu koji počinje idejama o samoubistvu, zatim progredira u planove samoubistva, pokušaje samoubistva i na kraju izvršeno samoubistva. S tim u vezi, vrlo je značajno prilikom procjene rizika od samoubistva uzeti u obzir utjecaj ranih, kao i nedavno proživljenih životnih događaja osobito kod vulnerabilnih pojedinaca koji imaju nedostatnu socijalnu podršku (Pompilli i sur., 2011).

U novije vrijeme istraživan je i utjecaj korištenja interneta na pojavu sklonosti samoubistvu, te je u vezi s tim transverzalna studija pokazala da pristup informacijama o metodama samoubistva i pro-suicidalnim 
web stranicama (koje aktivno potiču na samoubistvo) imaju manji, ali ipak još uvijek značajan i nezanemariv udio u sklonosti samoubistvu (Gunnel i sur., 2012).

\subsection{Psihijatrijski rizični faktori}

Od psihijatrijskih rizičnih faktora najprediktivniji za ponovljeni pokušaj samoubistva je prethodni pokušaj samoubistva i dešava se $u$ $30 \%$ slučajeva, dok se samoubistvo dešava u 10\% slučajeva (Haukka i sur., 2008). Također, značajna je i općenito povijest ponašanja koje sugerira sklonost samoubistvu i samoozljeđivanja (Cavanagh, 2003), te povijest izvršenog samoubistva u porodici, tj. hereditet (Aziraj-Smajić, 2014; Ruuhela i sur., 2009). Ipak, sto se tiče herediteta u litetaturi postoje oprečni podaci, te rezultati pojedinih studija sugeriraju da ne postoji značajna povezanost između sklonosti samoubistvu i povijesti izvršenog samoubistva u porodici (Hoyer, 2002; King i sur., 2001), kao ni povezanost između sklonosti samoubistva i povijesti poremećaja raspoloženja u porodici (Tsai i sur., 2002).

Značajan prediktor samoubistva je i psihijatrijski poremećaj (Ruuhela i sur., 2009). U kontroliranoj studiji slučaja i seriji slučajeva u kojima je primjenjivana metoda psihološke autopsije utvrđeno je da su oko $90 \%$ samoubistava izvršile osobe koje si imale dijagnozu psihijatrijskog poremećaja (Cavanagh, 2003). U poređenju s općom populacijom najveći rizik od pojave ideja o samoubistvu, pokušaja samoubistava i na koncu izvršenih samoubistava javlja se kod osoba sa shizofrenijom $\mathrm{i}$ to posebno u prodromalnim fazama bolesti (Andriopoulos, Ellul i Skokou, 2011). Rezultati dosadašnjih istraživanja upućuju na podatak da je sklonost samoubistvu vjerovatnija i češća u komorbiditetnim stanjima, tj. kada se uz primarnu dijagnozu određenog psihičkog poremećaja javlja još jedan ili više pridruženih psihičkih poremećaja. Naime, pokazano je da je sklonost samoubistvu kod osoba s PTSP-om najizraženija kada se uz osnovnu dijagnozu javi depresivni poremećaj raspoloženja, zatim poremećaji ličnosti (dominantno granični), zatim shizofrenija i bolesti ovisnosti (Aziraj-Smajić, 2013; 2014a).

Novije studije sve više ukazuju na značaj prisustva depresije kod određenih tjelesnih oboljenja, te se $s$ tim u vezi npr. sugerira snažan utjecaj ovog psihijatrijskog poremećaja na povišenu sklonost samoubistvu kod osoba oboljelih od temporalne epilepsije kod kojih je 
često prisutna i impulzivnost kao posljedica deficita izvršnih funkcija (de Oliveira, Kummer, Salgado, de Araujo Filho, David i Teixeira, 2011).

\subsection{Tjelesni rizični faktori}

Vrlo značajan prediktor sklonosti samoubistvu predstavljaju i tjelesni faktori. U prilog tome svjedoče i rezultati post mortem istraživanja koji upućuju na podatak da kod 25 do $75 \%$ žrtava samoubistva postoji neka tjelesna bolest (Marčinko, 2011). S tim u vezi, najčešće sklone samoubistvu su osobe s malignim bolestima, epilepsijom, multipla sklerozom (Giannini i sur., 2010), koje imaju koronarne i cerebrovaskularne bolesti, AIDS, hormonalne poremećaje, bubrežna oštećenja koja zahtijevaju dijalizu (Begić, 2012).

Nadalje, suicidolozi sugeriraju da se na tjelesne bolesti često nadovezuje psihijatrijska dijagnoza velikog depresivnog poremećaja koja tada predstavlja temelj za razvoj sklonosti samoubistvu (Marčinko, 2011). Huntingtonova bolest uz depresivni poremećaj značajno povećava rizik za izvršeno samoubistvo (Hubers, Reedeker, Giltay, Ross, Duijn i van der Mast, 2012).

Iz svega navedenog jasno je da svi pomenuti rizični faktori imaju značajnu ulogu u predikciji samoubistva i stoga je od nepobitnog značaja poznavati ih i dalje istraživati. Sve rečeno sažeto je predstavljeno u Tabeli 1.2.5.1.

Tabela 1. Pregled najznačajnijih rizičnih faktora za razvoj sklonosti samoubistvu

\begin{tabular}{|c|c|c|c|}
\hline $\begin{array}{c}\text { Sociodemograf } \\
\text { ski faktori }\end{array}$ & $\begin{array}{c}\text { Psihološki } \\
\text { faktori }\end{array}$ & $\begin{array}{c}\text { Psihijatrijski } \\
\text { faktori }\end{array}$ & $\begin{array}{c}\text { Tjelesni faktori } \\
\text { (tjelesne } \\
\text { bolesti) }\end{array}$ \\
\hline muški spol & osjećaj beznađa & $\begin{array}{c}\text { pokušaj } \\
\text { samoubistva }\end{array}$ & maligne bolesti \\
\hline niži SES & $\begin{array}{c}\text { povijest } \\
\text { ponašanja } \\
\text { osjećaj manje } \\
\text { vrijednosti } \\
\text { sklonost } \\
\text { samoubistvu }\end{array}$ & epilepsija \\
\hline
\end{tabular}




\begin{tabular}{|c|c|c|c|}
\hline $\begin{array}{l}\text { promijenjeni } \\
\text { bračni status }\end{array}$ & $\begin{array}{c}\text { trauma u } \\
\text { djetinjstvu }\end{array}$ & $\begin{array}{c}\text { psihijatrijski } \\
\text { hereditet }\end{array}$ & $\begin{array}{c}\text { koronarne } \\
\text { bolesti }\end{array}$ \\
\hline $\begin{array}{l}\text { niža razina } \\
\text { obrazovanja }\end{array}$ & $\begin{array}{c}\text { nedostatak } \\
\text { emocionalne } \\
\text { podrške }\end{array}$ & $\begin{array}{l}\text { psihijatrijski } \\
\text { poremećaj }\end{array}$ & $\begin{array}{l}\text { cerebrovaskula } \\
\text { rne bolesti }\end{array}$ \\
\hline $\begin{array}{c}\text { mlađa starosna } \\
\text { dob } \\
\text { (adolescenti) }\end{array}$ & $\begin{array}{l}\text { nizak IQ u općoj } \\
\text { populaciji }\end{array}$ & $\begin{array}{c}\text { komorbiditet } \\
\text { psihijatrijski } \\
\mathrm{h} \\
\text { poremećaja }\end{array}$ & $\begin{array}{l}\text { hormonalni } \\
\text { poremećaji }\end{array}$ \\
\hline $\begin{array}{c}\text { starija starosna } \\
\text { dob (preko } 60 \\
\text { godina) }\end{array}$ & $\begin{array}{c}\text { visok IQ u } \\
\text { psihijatrijskoj } \\
\text { populaciji }\end{array}$ & & AIDS \\
\hline \multirow[t]{2}{*}{ nezaposlenost } & $\begin{array}{c}\text { akutne } \\
\text { psihosocijalne } \\
\text { krize }\end{array}$ & & $\begin{array}{l}\text { multipla } \\
\text { skleroza }\end{array}$ \\
\hline & $\begin{array}{c}\text { anksiozna } \\
\text { osjetljivost,pesim } \\
\text { izam, } \\
\text { impulzivnost, } \\
\text { agresivnost kao } \\
\text { crte ličnosti }\end{array}$ & & $\begin{array}{c}\text { bubrežna } \\
\text { oboljenja koja } \\
\text { uključuju } \\
\text { dijalizu }\end{array}$ \\
\hline
\end{tabular}

\section{KLINIČKE IMPLIKACIJE}

Iz ovog preglednog rada proizilazi nekoliko kliničkih implikacija. S obzirom da su pokazani temeljni rizični faktori za razvoj sklonosti samoubistvu, psihološku procjenu vulnerabilnosti za sklonost samoubistvu je opravdano provoditi na kognitivnom, emocionalnom planu, te planu ličnosti. Dakle, pored autoanamnestički i hetermnestičkih podataka o sociodemografskim i tjelesnim rizičnim faktorima, za sveobuhvatnu procjenu je neophodno usmjeriti se na ispitivanje sposobnosti inteligencije, pamćenja, mišljenja, pažnje, koncentracije, izvršnih funkcija, s jedne strane, zatim obilježja ličnosti, prisustva psihopatološke simptomatike i općenito emocionalnog stanja pojedinca, s druge. Posebnu pažnju u procjeni je potrebno posvetiti osobama čija aktualna klinička slika zadovoljava kriterije za određeni 
psihički poremećaj i to pogotovo ukoliko uz osnovnu dijagnozu imaju i jedan ili više pridruženih poremećaja.

\section{ZAKLJUČAK I PREPORUKE}

Na temelju pregleda brojnih dosadašnjih istraživanja u ovom području, prema dostupnim podacima, determinirani su osnovni faktori koji se povezuju sa rizikom razvoja sklonosti samoubistvu i to na razini ideja o samoubistvu, te njegovih pokušaja i izvršenja. S obzirom na multifaktorijalnost pojave ovog fenomena osnovni je zaključak da nije opravdano pojednostavljivati odgovor na pitanje koja su to obilježja koja nekog pojedinca čine vulnerabilnijim za razvoj sklonosti samoubistvu od drugih. U kliničkoj procjeni rizika za razvoj sklonosti samoubistvu neophodno je uzeti u obzir međudjelovanje sociodemografskih, psiholoških, psihijatrijskih i tjelesnih faktora bez obzira da li se radi o općoj ili psihijatrijskoj populaciji.

Kao najsnažniji rizični faktor za razvoj sklonosti samoubistvu se pokazao prethodni pokušaj samoubistva. Ne manje važno je i prisustvo osjećaja beznađa koje se pokazalo čak daleko prediktivnije i od depresije koja predstavlja vrlo snažan rizični faktor za pojavu ideja o samoubistvu. Također, ovaj pregledni rad upućuje na podatak da su osobe s dijagnosticiranim psihičkim poremećajima pod većim rizikom za razvoj sklonosti samoubistvu, ali da je sklonost samoubistvu na svim razinama vjerovatnija i češća u komorbiditetnim stanjima.

Iz navedenih zaključaka proizilaze preporuke usmjerene na daljnje istraživanje ovog kompleksnog fenomena na svim njegovim razinama. U cilju prevazilaženja osnovnih metodoloških teškoća, a koje su naglašene u uvodnom dijelu preglednog rada, neophodno je sistematsko planiranje, primjena psihološkog instrumentarija sa zadovoljavajućim metrijskim karakteristikama, te usmjeravanje na longitudinalne istraživačke nacrte. Posebni naglasak u budućim istraživanjima se preporučuje $u$ sferi protektivnih faktora $u$ cilju identificiranja determinanti koje će kliničarima pomoći da procijene ravnotežu između zaštitnih i rizičnih faktora kod nekog pojedinca. Također, preporučuje se ispitivanje uloge dimenzija ličnosti, nedovoljno istraženih mehanizama koji leže u podlozi sklonosti samoubistvu (posebno u sferi rodnih specifičnosti), te općenito istraživanje sklonosti samoubistvu u širem psihosocijalnom kontekstu. 


\section{LITERATURA}

1. Acosta, F.J., Vega, D., Torralba, L., Navarro, S., Ramallo-Farina, J., Fiuza, D., Hernandez, J.L. i Siris, S.G. (2012). Hopelessness and suicidal risk in bipolar disorder. A study in clinically nonsyndromal patients. Comprehensive Psychiatry, 53, 1103-1109.

2. Agerbo, E., Qin, P. i Mortensenm, P.B. (2006). Psychiatric illness, socioeconomic status, and marital status in people committing suicide: a matched case-sibling-control study. Journal of Epidemiology Community Health, 60, 776-781.

3. Ahn, M.H., Park, S., Ha, K., Choi, H.S. i Hong, J.P. (2012). Gender ratio comparisons of the suicide rates and methods in Korea, Japan, Australia, and the United States. Journal of Affective Disorders, 142, $161-165$.

4. Ahs, A.M. i Westerling, R. (2006). Mortality in relation to employment status during different levels of unemployment. Scandinavian Journal of Public Health, 34, 159- 167.

5. Akrap, L. (2011). Procjena rizika suicidalnosti: psihološka procjena suicidalnog ponašanja. U: Marčinko, M. (ur.), Suicidologija. (str. 3544). Zagreb: Medicinska Naklada.

6. Alaräisänen, A., Heikkinen, J., Kianickova, Z., Miettunen, J., Räsänen, P. i Isohanni, M. (2007). Pathways leading to suicide in schizophrenia. Current Psychiatry Review, 3, 233-242.

7. Andriopoulos, I., Ellul, J. i Skokou, M. (2011). Suicidality in the "prodromal" phase of schizophrenia. Comprehensive Psychiatry, 52, $479-475$.

8. Asmundson, G.J.G., Coons, M.I., Taylor, S. i Katz, J. (2002). PTSD and experience of pain: Research and clinical implications of shared vulnerability and mutual maintenance models. Canadian Journal of Psychiatry, 47, 930-937.

9. Aziraj-Smajić, V. (2013). Pregled istraživanja sklonosti samoubojstvu u osoba s PTSP-om. Neobjavljeni specijalistički rad. Odsjek za psihologiju. Filozofski fakultet u Zagrebu.

10. Aziraj-Smajić, V. (2014a). Obilježja ličnosti s obzirom na status suicidalnosti kod osoba s PTSP-om. Neobjavljena doktorska disertacija. Odsjek za psihologiju. Filozofski fakultet u Sarajevu.

11. Aziraj-Smajić, V. (2014b). Simptomi PTSP-a kao prediktivni faktori suicidalnosti u osoba s PTSP-om. Dani psihologije u Zadru.

Filozofski fakultet u Zadru. 
12. Barett, A.E., Sundet, K., Faerden, A., i sur. (2010). Suicidality before and in early phases of first episode psychosis. Schizophrenia Research, 119, 11-17.

13. Beck, A.T. i Weishaar, M.E. (1990). Suicide Risk Assessment and Protection. Crisis 11, 22-30. Beck, A.T., Brown, G. i Steer, R.A. (1989). Prediction of eventual suicide in psychiatric patients by clinical ratings of hopelessness. Journal of Consulting Clinical Psychology, 57, 309-310.

14. Begić, D. (2011). Suicidalnost. U: Begić, D. (ur.), Psihopatologija. (str. 391-397). Zagreb: Medicinska Naklada.

15. Bernert, R. A., Joiner, T. E., Cukrowicz, K. C., Schmidt, N. B. i Krakow, B. (2005). Suicidality and sleep disturbances. Sleep 28, 1135-1141. Blakely, T.A., Collings, S.C.D. i Atkinson, J. (2003). Unemployment and suicide. Evidence for a causal association? Journal of Epidemiology Community Health 57, 594-600.

16. Blakely, T.A., Collings, S.C.D. i Atkinson, J. (2003). Unemployment and suicide. Evidence for a causal association? Journal of Epidemiology Community Health, 57, 594-600.

17. Borges, G., Angst, J., Nock, M.K., Ruscio, A.M., Walters, E.E., Kessler, R.C. (2006). A Risk Index for 12-Month Suicide Attempts in the National Comorbidity Survey Replication (NCS-R). Psychological Medicine, 36, (12), 1747-1757.

18. Branney, P. i White, A. (2008). Big boys don't cry: depression and men. Advances in Psychiatric Treatment 14, 256 - 262.

19. Capron, D.W., Blumenthal, H., Medley, A.N., Lewis, S., Feldner, M.T., Zvolensky, M.J. i Schmidt, N.B. (2012). Anxiety sensitivity cognitive concerns predict suicidality among smokers. Journal of Affective Disorders, 138, 239-246.

20. Capron, D.W., Cougle, J.R., Ribeiro, D.J., Joiner, T.E. i Schmidt, N.B. (2011). An interactive model of anxiety sensitivity relevant to suicide attempt history and future suicidal ideation. Journal of Psychiatric Research, 46, 174-180.

21. Capron, D.W., Fitch, K., Medley, A., Blagg, C., Mallott, M. i Joiner, T. (2011). Role of anxiety sensitivity subfactors in suicidal ideation and suicide attempt history.

Depression and Anxiety, 29, 195-201.

22. Cavanagh, J., Carson, A., Sharpe, M., i Lawrie, S. (2003).

Psychological autopsy studies of suicide: a systematic review.

Psychological Medicine, 33, 395-405. 
23. Daniel, S.S. i Goldston, D.B. (2012). Hopelessness and Lack of Connectedness to Others as Risk Factors for Suicidal Behavior Across the Lifespan: Implications for Cognitive-Behavioral Treatment. Cognitive and Behavioral Practice, 19, 288 - 300.

24. de Oliveira, G.N.M., Kummer, A., Salgado, J.V., de Araujo Filho, G.M., David, A.S. i Teixeira, A.L. (2011). Suicidality in temporal lobe epilepsy: Measuring the weight of impulsivity and depression. Epilepsy \& Behavior, 22, 745-749.

25. Federalni zavod za zapošljavanje (2012). Bilten: Statistički pregled Januar/Siječanj 2012. Sarajevo.

26. Federalni zavod za zapošljavanje (2016). Bilten: Statistički pregled Januar/Siječanj 2016. Sarajevo.

27. Garcia - Espinosa, A., Machado, R.A., Gonzalez, S.B., Gonazalez, M.E., Montoto, A.P. i Sotomayor, G.T. (2010). Wisconsin Card Sorting Test performance and impulsivity in patients with temporal lobe epilepsy: Suicidal risk and suicide attempts. Epilepsy \& Behavior, 17, $39-45$.

28. Giegling, I., Ogliati, P., Hartmann, A.M., Calati, R., Moler, H.J., Rujescu, D. i Sarretti, A., (2009). Personality and attempted suicide. Analysis of anger, aggression and impulsivity. Journal of Psychiatric Research, 43, 1262-1271.

29. Gunnel, D., Bennewith, O., Kapur, N., Simkin, S., Cooper, J. i Hawton, K. (2012). The use of the Internet by people who die by suicide in England: A cross sectional study. Journal of Affective Disorders, 141, 480 - 483.

30. Gunnell, D., Middleton, N., Whitley, E., Dorling, D. i Frankel, S. (2003). Why are suicide rates raising in young men but falling in the eldery? A time series analyses of trends in England and Wales 19501998. Social Sciences and Medicine, 57, 595-611

31. Harriss, A.C. i Barraclough, B. (1998). Excess mortality of mental disorder. British Journal od Psychiatry, 173, 11-53.

32. Haukka, J., Suominen, K., Partonen, T. i Lönnqvist, J. (2008). Determinants and outcomes of serious attempted suicide: a nationwide study in Finland, 1996-2003. American Journal of Epidemiology, 167, 1155-1163.

33. Hawton, K., Sutton, L., Haw, C., Sinclair, J., Harriss, L. (2005). Suicide and attempted suicide in bipolar disorder: a systematic review of risk factors. Journal of Clinical Psychiatry 66, 693-704. Hawton, K., Sutton, L., Haw, C., Sinclair, J. 
i Deeks, J. (2005). Schizophrenia and suicide: systematic review of risk factors. The British Journal of Psychiatry, 187, 9-20.

34. Holmes, R. M. i Holmes, S. T. (2005). Suicide: Theory, practice and investigation. Thousand Oaks, CA: Sage Publications, Inc.

35. Hubers, A.A.M., Reedeker, N., Giltay, E.J., Ross, R.A.C., van Duijn, E., i van der Mast, R.C. (2012). Suicidality in Huntington's disease. Journal of Affective Disorders, 136, 550 - 557.

36. Jokić-Begić, N. (2005). Odnos inteligencije i intenziteta posttraumatskog stresnog poremećaja: retrospektivna studija na hrvatskim ratnim veteranima. Socijalna psihijatrija 33, 173-182.

37. Lazary, J., Viczena, V., Dome, P., Chase, D., Juhasz, G. i Bagdy, G. (2012). Hopelessness, a potential endophenotpye for suicidal behavior, is influenced by TPH2 gene variants. Progress in NeuroPsychopharmacology and Biological Psychiatry, 36, 155 - 160.

38. Lorant, V., Kunst, A.E., Huisman, M., Bopp, M. i Mackenbach, J. (2005). A European comparative study of marital status and socioeconomic inequalities in suicide.

Social Science \& Medicine 60, 2431-2441.

39. Lundin, Lundberg, Allebeck i Hemmingsson, (2012).

Unemployment and suicide in the Stockholm population: A registerbased study on 771,068 men and women. Public Health, 126, $371-377$.

40. Kaminski, J.W., Puddy, R.W., Hall, D.M., Cashman, S.I., Crosby, A.E. i Ortega, A.G. (2010). The relative influence of different domains of social connectedness on selfdirected violence in adolescence. Journal of Youth and Adolescence, 39, 460-473.

41. Kim, C.H., Jayathilake, K. i Meltzer, H.I. (2003). Hopelessness, neurocognitive function, and insight in schizophrenia: Relationship to suicidal behaviour. Schizophrenia Research 60, 71-80.

42. King, E.A., Baldwin, E.S., Sinclar, J.M. Baker, N.G.,Campbell, M. i Thompson, C. (2001). The Wessex Recent in Patient Suicide Study 1: case control f 234 recently disharged psychiatric patient suicides. British Journal of Psychiatry, 178, 531-536.

43. Mäki, N., Martikainen, P. (2007). Socioeconomic differences in suicide mortality by sex in Finland 1971-2000: a register-based study of trends, levels, and life expectancy differences. Scandinavian Journal of Public Health, 35, 387-395. 
44. Maltzer, H.Y. (1998). Suicide in shizophrenia: risk factors and clozapin treatment. Journal of Clinical Psychiatry 59, 15-20.

45. Marčinko, D. i suradnici (2011). Modeli razumijevanja suicidalnog ponašanja. U: Marčinko, D.. (ur.), Suicidologija. (str. 15-23). Zagreb: Medicinska naklada.

46. Marshall, R. D., Olfson, M., Hellman, F., Blanco, C., Guardino, M., i Struening, E. L. (2001). Comorbidity, impairment, and suicidality in subthreshold PTSD. American

Journal of Psychiatry, 158, 1467-1473.

47. Mastekaasa, A. (2006). Is marriage/cohabitation beneficial for young people? Some evidence on psychological distress among Norwegian college students. Journal of Community and Applied Social Psychology, 16, 149-165.

48. Morrison, R. i O'Connor, R.C. (2008). A systematic review of the relationship between rumination and suicidality. Suicide \& LifeThreatening Behavior, 38, 523-538.

49. Nadorff, M.R., Anestis, MD, Nazem, S., Harris, C.H i Winer, S.E. (2014). Sleep disorders and the interpersonal-psychological theory of suicide: Independent pathways to suicidality? Journal of Affective Disorders 505, 152-154.

50. Nangle, J.M., Clarke, S., Morris, D.W., Schwaiger, S., McGhee, K.A., Kenny, N., Murphy, K., Gill, M., Corvin, A. i Donohoe, G. (2006). Neurocognition and suicidal behaviour in an Irish population with major psychotic disorders. Schizophrenia Research, 85, 196-200.

51. Niméus, A., Träskman-Bendz, L. i Alsén, M. (1997). Hopelessness and suicide behavior. Journal of Affective Disorders 42, 137-144.

52. O'Connor, R.C. i Noyce, R. (2008). Personality and cognitive processes: Self-criticism and different types of rumination as predictors of suicidal ideation. Behaviour Research and Therapy, 46, $392-401$.

53. Pitman, A., Krysinska, K., Osborn, D. i King, M. (2012). Suicide in young men. The Lancet, 379, 2383-2392.

54. Pompilli, M., Vichi, M., Qin, P., Innamorati, M., De Leo, D. i Girardi, P. (2012). Does the level of education influence completed suicide? A nation wide register study. Journal of Affective Disorders, 147, 437-440. 
55. Portzky, G., Audenaert, K. i Van Heeringen, K. (2005). Adjustment disorder and the course of the suicidal process in adolescents. Journal of Affective Disorders 87, 265-270.

56. Power, P.J.R., Bell, J.R., Mills, R., Herrman-Doig, T., Davern, M., i Henry, L. (2003). Suicide prevention in first episode psychosis: the development of cognitive therapy for acutely suicidal patients with early psychosis. Australian and New Zealand Journal of Psychiatry, 37, 414-420.

57. Qin, P., Agerbo, E. i Mortensen, P.B. (2003). Suicide risk in relation to socioeconomic, demographic, psychiatric, and familial factorsa national register-based study of all suicides in Denmark, 1981-1997. American Journal of Psychiatry, 160, 765.

58. Rasmussen, S.A., Elliott, M.A. i O' Connor, R.C. (2012). Psychological distress and perfectionism in recent suicide attempters: The role of behavioural inhibition and activation. Personality and Individual Differences, 52, 680 - 685.

59. Resnik, P.J. (2002). Recognizing that the suicidal patient views you as an adversary. Current Psychiatry 1.

60. Ruhella, R., Hiltunen, L., Vanalainen, A., Pirinen, P. i Partonen, T. (2009). Climate impact on suicide rates in Finland from 1971 to 2003. International Journal of Biometorology, 53, 167 - 175.

61. Sarchiapone, M., Jovanović, N., Roy, A., Podlesek, A., Carli, V., Amore, M., Mancini, M. i Marušić, A. (2009). Relations of psychological characteristics to suicide behaviour: Results from a large sample of male prisoners. Personality and Individual Differences, 47, 250 - 255.

62. Sareen, J., Cox, B.J., Clara, I. i Asmundson, G.J.G. (2005).

Relationship between anxiety disorders and physical disorders in the U.S. national comorbidity survey.

Depression and Anxiety, 21, 193-202.

63. Shmidt, R.E., Gay, P., Ghisletta, P. i Van der Linden, M. (2010).

Linking impulsivity to disfunctional thought control and insomnia: a structural equation model. Journal of Sleep Research, 19, 3-11.

64. Simpson, T., Jakupcak, M. i Luterek, J.A. (2006). Fear and avoidance of internal experiences among patients with substance use disorders and PTSD: the centrality of anxiety sensitivity. Journal of Traumatic Stress, 19, 481-491. 
65. Spokas, M., Wenzel, A., Brown, G.K. i Beck, A.T. (2012). Characteristics of individuals who make impulsive suicide attempts. Journal of Affective Disorders, 136, 1121 - 1125.

66. Stack, S. (2000). Suicide: a 15-year review of the sociological literature part II: modernization and social integration perspectives. Suicide and Life-Threatening, 30, 163-176.

67. Suokas, J, Suominen K., Heilä H., et al. (2010). Attempted suicide in mental disorders in young adulthood. Social Psychiatry and Epidemiology, 24, 72-82.

68. Tsai, M. S.Y., Kuo, C.J., i Lee, H.C. (2002). Risk factors for completed suicide in bipolar disorder. Journal of Clinical Psychiatry, 63, $469-476$.

69. van Heeringen, K. (2001). The Suicidal Process and Related Concepts. U: K. van Heeringen (Ur.), Understanding suicidal behaviour: the suicidal process approach to research, treatment and prevention (str. 3-14). Chichester: John Willey i Sons LTD.

70. Vigil-Colet, A. i Codorniu-Raga, M.J. (2004). Aggresion and inhibition deficits, the role of functional and dysfunctional impulsivity. Personality and Individual Differences, 37, 135-170.

71. Yim, P.H.W., Yip, P.S.F., Li, R.H.I., Dunn, E.L.W., Yeung, W.S. i Miao, Y.K. (2004). Suicide after discharge from psychiatric inpatient care: a case-control study in Hong Kong. Australian \& New Zealand Journal of Psychiatry, 38, 65-72.

72. WHO-World Health Organization. (2005) Distribution of Suicides Rates (per 100,000) by Gender and Age, 2000. World Health Organisation, Geneva, Switzerland. 
dr. sc. Vildana Aziraj-Smajić, clinical psychology specialist RISK FACTORS FOR DEVELOPMENT OF SUICIDALIT

\section{Summary}

There is a significant interest of researchers for examining the presence of risk factors for development of suicidality at the level of ideas about suicide, suicide attempts and committed suicide. The objective of this review paper is to provide a clear and concise review of scientific knowledge about socio-demographic, psychological, psychiatric and physical risk factors for development of suicidality, and to answer questions about the mechanisms that determine their relationships. The paper is based on reference literature from the field of suicidality, with an emphasis on research published in the past fifteen years.

On the basis of a short review of present knowledge and available data, it has been concluded that there is strong evidence of the presence of certain sociodemographic, psychological, psychiatric and physical risk factors that may make an individual vulnerable to development of suicidality at any level. Accumulation of these risks results in an increase of risk of suicide. Clinical implications of this review paper include the possibility of practical application of scientifically based results of research and their application in clinical practice with the purpose of improving psychological assessment of suicidality. Timely recognition, detection and treatment of risk factors is a key component for developing a strategy of prevention of suicidality, as well as determining the most appropriate form of intervention.

Key words: suicidality, suicidal ideas, suicidal attempts, suicide, risk factors 
الدكتورة فيلدانا آزيراي - سماييتش - أخصائية في علم النفس السريري'

عوامل الخطر لتنمية الميل إلى الانتحار

\section{الخلاصية}

يوجد اهتمام كبير لدى الباحثين لدراسة وجود عوامل الخطر لتنمية الميل للانتحار

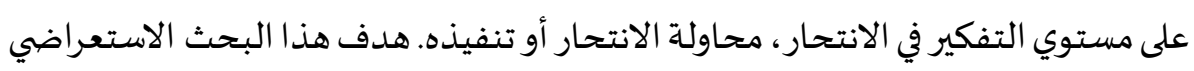
تقديم العرض الواضح والمختصر للمكتشفات العلمية حول عوامل الخطر الاجتماعية

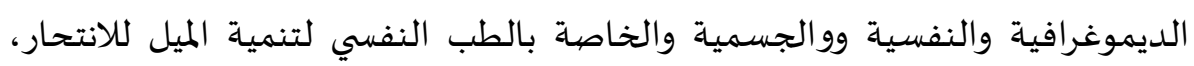

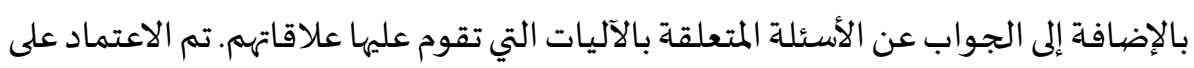

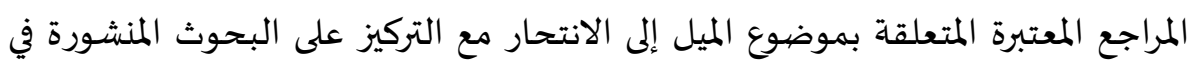
خمسة عشر سنة الأخيرة.

بناء على العرض الناقد للإنجازات التي تم تحقيقها إلى الآن، حسب المعرة المعلومات

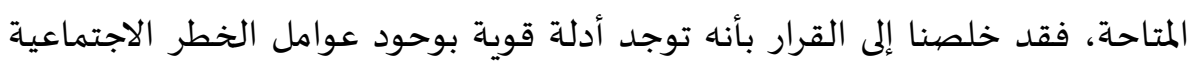

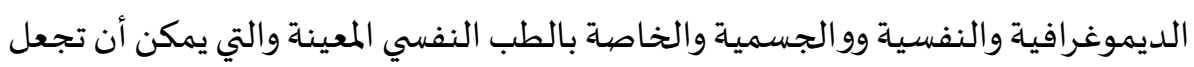

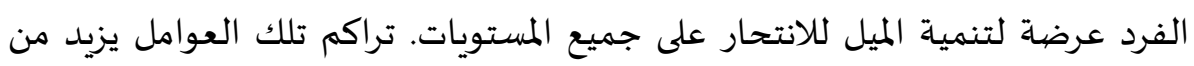

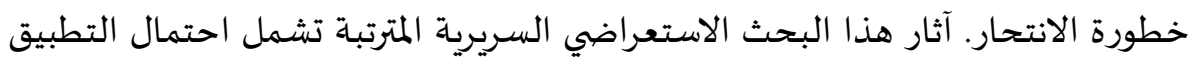

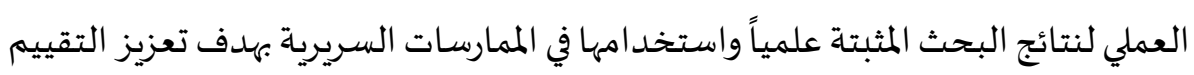
النفسي للميل للانتحار. إن اكتشاف عوامل الخطر والتعرف عليها في حينها والعمل بموجبها

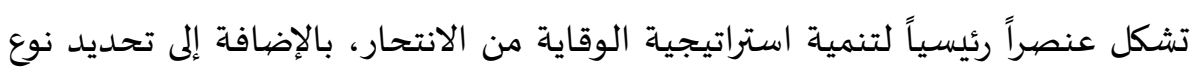

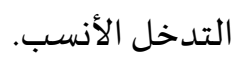

الكلمات الرئيسة: الميل إلى الانتحار، التفكير في الانتحار، محاولة الانتحار، تنفيذ الانتحار، عوامل الخطر 